\title{
Két generációban megfigyelhető mitokondriális DNS A8344G mutáció
}

\author{
Fekete Anett dr. ${ }^{1}$ - Hadzsiev Kinga dr. ${ }^{1,2}$ - Bene Judit dr. ${ }^{1,2}$ \\ Nászai Antónia dr. ${ }^{3}$. Mátyás Petra ${ }^{1}$. Till Ágnes dr. ${ }^{1}$ - Melegh Béla dr. ${ }^{1,2}$ \\ ${ }^{1}$ Pécsi Tudományegyetem, Általános Orvostudományi Kar, Klinikai Központ, Orvosi Genetikai Intézet, Pécs \\ ${ }^{2}$ Szentágothai János Kutatóközpont, Pécs \\ ${ }^{3}$ Encsi Területi Egészségügyi Központ, Ideggyógyászat, Encs
}

\begin{abstract}
Közleményünkben egy 62 éves anya és 41 éves lánya esetét ismertetjük. A mater neurológiai tünetei több évtizede ismertek, lányánál pedig 15 éves kivizsgálás után került sor a betegségdiagnosztizálásra. Intézetünkben a perifériás vérből izolált DNS-mintán indult célzott vizsgálat mitokondriális mutáció irányába. A szekvenciaferogram alapján 90\% feletti heteroplazmiát mutató tranzíciót sikerült kimutatni. A klinikai fenotípus kétséget kizáróan egyik esetben sem volt karakterisztikus MERRF-szindrómára; a felnőttkori észlelés mellett a lipomák jelenléte sem típusos. Az évtizeden túli diagnosztikai Odüsszeia itt is arra utal, hogy hazánkban a mitokondriális DNS betegségei még mindig aluldiagnosztizáltak. Orv. Hetil., 2017, 158(12), 468-471.
\end{abstract}

Kulcsszavak: MERRF, lipoma, mitokondriális DNS

\section{A8344G mitochondrial DNA mutation observed in two generations}

\begin{abstract}
This article presents the case of a 62-year-old mother and her 41-year-old daughter, who have had severe neurological symptoms for a few decades. After a long investigation period the definite diagnosis of MERRF syndrome was confirmed. After DNA isolation from our patient's blood sample we examined the mitochondrial DNA with direct sequencing. An adenine-guanine substitution was detected in the tRNA gene at position 8344, based on the sequence ferogram the heteroplasmy was over $90 \%$. The clinical phenotype was not clearly characteristic for MERRF syndrome, adult-onset and lipomas are not typical in this disease. In our case report we would like to draw attention to the great phenotypic variation of the mitochondrial diseases and we emphasize that these disorders are underdiagnosed in Hungary even today.
\end{abstract}

Keywords: MERRF, lipoma, mitochondrial DNA

Fekete, A., Hadzsiev, K., Bene, J., Nászai, A., Mátyás, P., Till, Á., Melegh, B. [A8344G mitochondrial DNA mutation observed in two generations]. Orv. Hetil., 2017, 158(12), 468-471.

(Beérkezett: 2016. október 6.; elfogadva: 2017. január 23.)

\begin{abstract}
Rövidítések
APTX = aprataxin; l-es típusú ataxia oculomotor apraxia; EDTA $=$ etilén-diamin-tetraecetsav; EEG $=$ elektroenkefalográfia; ENG = elektroneurográfiai; DRPLA = dentatorubral-pallidoluysian atrophia; FRDA = Friedreich-ataxia; $\mathrm{MERRF}=$ (myoclonus epilepsy - ragged red fibers) myoclonus epilepszia - ragged red fibers (rongyos vörös izomrostok); mtDNS = mitokondriális DNS; NARP = neuropathia, ataxia, retinitis pigmentosa; $\mathrm{PCR}=$ polimeráz láncreakció; $\mathrm{SCA}=$ spinocerebellaris ataxia; SETX = senataxin; 2 -es típusú ataxia oculomotor apraxia; TTPA $=($ tocopherol transfer protein alpha $)$ ataxia szelektív E-vitamin-hiánnyal
\end{abstract}

A MERRF-szindróma egy ritka genetikai betegség, amely a szervezet múködésének számos területére kihat, elsősorban az izomzat és az idegrendszer érintettek. A szindróma elnevezése az angol elnevezésből származó mozaikszó, amely a fő klinikai jellemzőket foglalja össze: myoclonus epilepszia - ragged red fibers (rongyos vörös izomrostok).

A tünetek jelentkezhetnek már gyermekkorban vagy normális élettani fejlődést követően felnőttkorban is, és rendkívül variábilis képet mutatnak [1]. Leggyakrabban előforduló tünet a myoclonus epilepszia, amely a végta- 
gok sorozatban jelentkező villámgyors ritmusos mozgásával jár. Társuló tünetként jelentkezhet halláskárosodás, progresszív internuclearis ophthalmoplegia, nystagmus, izomgyengeség, járási bizonytalanság, ataxia, a szellemi funkciók lassú romlása, valamint a beszéd nehezítettsége. Ritkább esetben előfordulhat perifériás neuropathia, cardiomyopathia, arrhythmia, valamint kialakulhatnak lipomák is, amelyek általában a nyak környékén helyezkednek el [1]. Gyakran laborvizsgálattal laktátacidózis mutatható ki, amely aspecifikus tüneteket, hányást, hasi fájdalmat, étvágytalanságot okozhat $[1,2]$.

A MERRF-szindróma diagnosztikája általában három alappilléren nyugszik: EEG-vizsgálat, izombiopszia és molekuláris genetikai vizsgálat. Myoclonus epilepszia esetén az EEG pozitív eredményt adhat: generalizált lassulás mellett epileptiform potenciálok észlelhetők az EEG-n. Izombiopszia során nyert szövetminta Gömöriféle trichrom festéssel jellegzetes fénymikroszkópos képet mutat, amelyet az angol nómenklatúra 'ragged red fibers' néven használ [2].

A MERRF-szindrómát a mitokondriális DNS mutációja okozza, amelynek következtében az oxidatív foszforilációs út múködése károsodik. A sejtek az ionegyensúly felbomlására hyperexcitabilitassal reagálnak, a foszforilációs útvonal károsodása energiadeficit révén pedig sejthalálhoz vezet. Az esetek körülbelül $80 \%$-ában a tRNS génben, a 8344-es pozícióban egy adenin $\rightarrow$ guanin cserét lehet kimutatni a tünetek hátterében $[3,4]$.

A klinikai tünetek változatosságát és azok súlyosságát a mitokondriális DNS-mutáció aránya, vagyis a heteroplazmia foka határozza meg. Különböző szöveteket, sejttípusokat vizsgálva, eltérő arányban találhatunk mutáns és vad típusú mitokondriális DNS-t. Minél nagyobb egy sejten belül a mutációt hordozó mitokondriális DNS aránya, annál súlyosabb érintettséggel kell számolni. Ez a jelenség az alapja annak, hogy MERRF-szindróma esetében egy adott családon belül is széles határok között változik a fenotípus [5-7].

A betegség prognózisa attól függ, hogy milyen szervi érintettsége van a betegnek, illetve, hogy mennyire gyakoriak az epilepsziás epizódok. Oki terápia hiányában csak tüneti kezelésekre van lehetôség, illetve a progreszszió valamelyest átmenetileg lassítható bizonyos vitaminok és ásványi anyagok (L-karnitin, koenzim-Q10) fokozott bevitelével [7].

\section{Esetismertetés}

Intézetünkben egy 41 éves nóbeteget vizsgáltunk, akit körülbelül egy évtizede kezdődött progrediáló ataxia, elkent beszéd, lipomák és polineuropathiás tünetek miatt kezeltek neurológián.

A családi anamnéziséből kiemelendő, hogy betegünk édesanyját évtizedek óta vizsgálták ismeretlen eredetü encephalomyopathia miatt. Tarkó- és válltáji lipomák miatt több alkalommal operálták, és a klinikai képhez 1994-ben epilepszia is társult. Az elvégzett koponya-

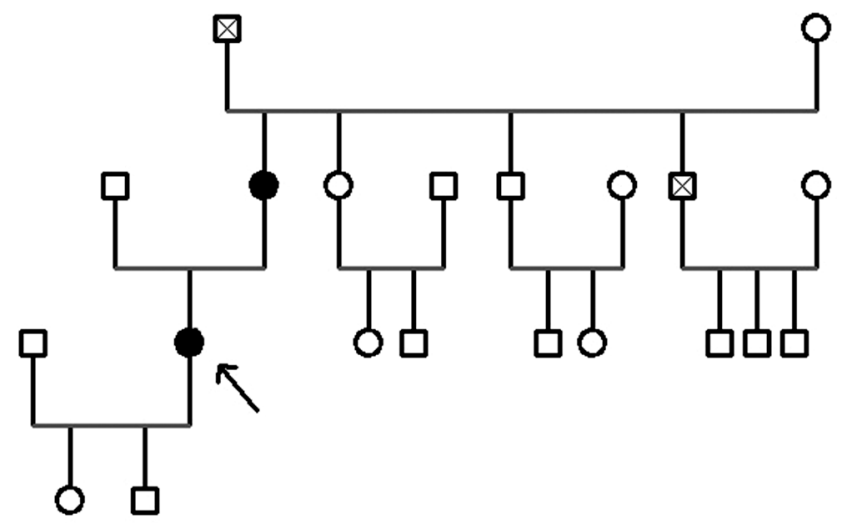

1. ábra | Betegünk családfája az érintett családtagok kiemelésével

MR-vizsgálat frontoparietalisan mérsékelten tág liquortereket írt le. Neurológiai státuszából kiemelhető areflexia, végtagi izomatrophia, súlyos végtagataxia, ataxiás járás, valamint incontinentia urinae. Felmerült Friedreich-ataxia és spinocerebellaris ataxia diagnózisa, de ilyen irányú genetikai vizsgálatok nem történtek. Betegünk anyai nagybátyjának is generalizált lipomái vannak, azonban neurológiai jellegú panaszai jelenleg nincsenek. Egyebekben a családi anamnézis negatív (1. ábra).

A probanda körülbelül 16 éves kora óta tapasztal a lábszár izomzatában időszakosan izomgörcsöket. 27-28 éves korában két alkalommal tarkótáji lipoma eltávolítása történt. 34 évesen kezdődött kézremegése; egyensúlya bizonytalanná vált, sokszor elesett; beszédének ritmusa megváltozott, elkentté vált. A tünetek fokozatosan váltak egyre kifejezettebbé. Az utóbbi években időnként fekvő helyzetben kettős látásra, valamint derékfájdalomra panaszkodik. Járás közben nagyon hamar elfárad. Hangulatingadozás, depresszió miatt pszichiátriai gondozásra szorul. Deréktáji, a jobb comb hátulsó részébe sugárzó fájdalma hátterében gerinc-MR-vizsgálattal discopathia, lumbalis IV-V. csigolya protrusiója igazolódott.

A 38 éves korában készült koponya-MR-vizsgálat atrophia cerebellit és a cella media magasságában frontalisan subcorticalisan, valamint a nucleus caudatus feji régiójában kis demyelinisatiós gócokat írt le. A rutin-EEGvizsgálat megtartott háttértevékenység mellett generalizált tüskehullámokat igazolt, azonban a betegnek klinikai rohama nem volt.

Szemészeti vizsgálat kóros eltérést nem írt le, KayserFleischer-gyứrút nem találtak, ami a fiatalkori ataxia hátterében felmerült Wilson-kórt nem támasztotta alá. Szintén nem utalt rézanyagcsere-zavarra a koponya-MRvizsgálat sem. Szérumcöruloplazmin-szint normáltartományban volt, gyűjtött vizeletból réztartalom-meghatározás nem történt.

ENG-vizsgálat a perifériás idegek szenzoros rostjaiban alsó végtagi túlsúllyal közepes fokú axonalis, szenzoros neuropathia jeleit detektálta; a motoros rostokban vezetési zavar nem volt kimutatható. 
Részletes anyagcsere-vizsgálat történt: tömegspektrometriás aminosav és acilkarnitin-meghatározás normális eredményt adott, szukcinilaceton-koncentrációban eltérés nem volt kimutatható. $\mathrm{B}_{12}$-vitamin-, folsav- és homociszteinszint-meghatározás kóros eltérést nem igazolt.

Ezt követően került a beteg intézetünk látóterébe, mivel az etiológia tisztázására a domináns (NARP, SCA-1,2,-3,-6,-7,-17, DRPLA) és recesszív ataxiák (FRDA, TTPA, APTX, SETX) irányába is kértek molekuláris genetikai tesztelést, azonban patogén mutáció nem volt azonosítható. Mivel valószínúsíthető volt a tünetek genetikai eredete, a további diagnosztikus lépések meghatározásához a beteget genetikai tanácsadónkba rendeltük. Az első megjelenésekor fizikális vizsgálattal belszervi státuszában kóros eltérést nem találtunk. Neurológiai státuszában renyhébb mélyreflexek, felső végtagi myoclonusok, skandáló, kissé elmosott beszéd, jelzett törzsés végtagataxia, kivájt láb, horizontális nystagmus és jelzett dysdiadochokinesis volt megfigyelhető. A háton és nyakon nagy kiterjedésű lipomák voltak láthatók. A neurológiai és az organikus tünetek alapján ekkor merült fel a mitokondriális eredet gyanúja.

\section{Módszer}

A DNS-izolálást EDTA-val alvadásgátolt vérmintákból végeztük kisózásos technika segítségével. Az izolált DNS-mintát a következő lépésben PCR-technikával amplifikáltuk. A PCR-reakció kivitelezése 35 cikluson keresztül a következő paraméterekkel történt: denaturáció $30 \mathrm{~s} 95^{\circ} \mathrm{C}$-on, primerkötődés $30 \mathrm{~s} 55^{\circ} \mathrm{C}$-on, polimerizáció $72{ }^{\circ} \mathrm{C}$-on $30 \mathrm{~s}$, majd a ciklusok végén végső lánchosszabbítás $72{ }^{\circ} \mathrm{C}$-on öt percig. Az amplifikáció MJ Research PTC 200 thermal cycler PCR-készülékkel valósult meg. A PCR-termék további vizsgálata gélelektroforézissel 2\%-os agarózgélben, etídium-bromidos festéssel és UV-megvilágítással történt.

A PCR után a mitokondriális DNS kérdéses szakaszát vizsgáltuk direkt szekvenálással a következő eltérésekre fókuszálva: A8296G, A8344G, T8356C, G8361A, G8363A. A vizsgálathoz használt forward primer: 5'-GTTTCATGCCCATCGTCCT-3' és reverse primer: 5'-GGGCAATGAATGAAGCGAAC-3' .

\section{Eredmények}

MERRF-szindróma irányába végzett mitokondriális DNS-vizsgálat során patogén mutációt azonosítottunk: a mitokondriális tRNS génben, a 8344-es pozícióban egy $\mathrm{A} \rightarrow \mathrm{G}$ cserét detektáltunk heteroplazmiás formában (2. ábra). A leletet genetikai tanácsadás keretein belül személyesen adtuk át a betegnek, a felmerült kérdésekre válaszoltunk.

A becsülhető heteroplazmia 90\% feletti lehet. Mivel ezen adatnak terápiás konzekvenciája nincsen, további kvantitálástól, invazív beavatkozástól (biopszia) - a beteg kérésének megfelelően - eltekintettünk.

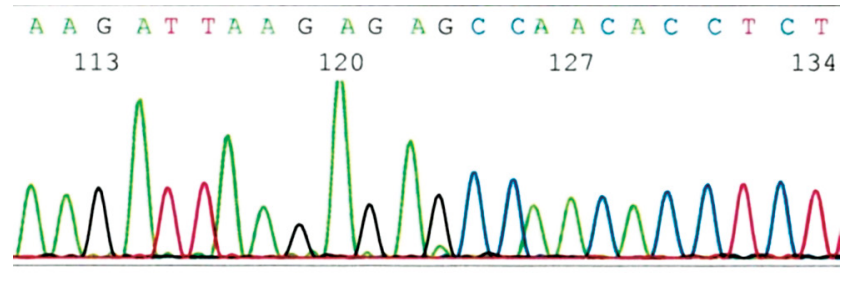

\begin{tabular}{l|l} 
2. ábra & Forward szekvencia
\end{tabular}

A MERRF-szindróma maternalis öröklődést mutat, így kezdeményeztük betegünk anyai ágú rokonainak a vizsgálatát is. Természetesen elsőként a diagnózis nélküli, szintén neurológiai tüneteket mutató édesanya került vizsgálatra, akinél ki tudtuk mutatni a mitokondriális DNS mutációját. Betegünk gyermekei még kiskorúak, így a 2008/XXI-es, a humángenetikai adatok védelmérôl szóló törvény értelmében náluk egyelőre molekuláris genetikai vizsgálat nem történhet.

\section{Megbeszélés}

Jelen közleményünk a mitokondriális DNS-mutáció okozta MERRF-szindróma bemutatását célozza meg és hangsúlyozza a klinikai tünetek nagyfokú variabilitását [8-11]. A ritka genetikai betegségek diagnosztikája mindig nagy kihívás elé állítja a szakma képviselőit, különös tekintettel a multiszisztémás betegségek heterogén csoportját alkotó mitokondriális citopathiák tekintetében.

Betegünk vizsgálata során DNS-szekvenálással jutottunk el a diagnózishoz. Ezzel a diagnosztikus módszerrel a mitokondriális heteroplazmia arányát csak szemikvantitatív módon tudtuk meghatározni, azonban miután a printen az eredeti nukleinsavpeak csak nyomokban detektálható, még a perifériás vér DNS-ben is 90\% feletti arányban, mind a probandában és az édesanyjában is, semmi értelmét nem láttuk az invazívabb vizsgálatnak, különösképpen, miután annak terápiás konzekvenciája nem lett volna.

A célzott genetikai vizsgálat indítása előtt mindkét betegünknél észlelt két klinikai tünet, az ataxia és a lipomák szokatlan kombinációját tartottuk szem előtt, amely egyéb, differenciáldiagnosztikai szempontból szóba jöhető kórképet kizárt.

\section{Következtetés}

Betegeinknél az irodalmi adatok alapján a leggyakoribbnak tartott mutáció hordozása volt kimutatható, a klaszszikus tünetekhez képest azonban a probandánál és édesanyjánál döntően cerebellaris tüneteket észleltünk. A magas heteroplazmia-arány ellenére viszonylag későn, már felnőttkorban manifesztálódtak a tünetek. A maternél 40 éves életkorban már jelentkezett epileptiform rosszullét, míg lányánál a pozitív rutin EEG mellett sem volt klinikai roham. A MERRF-szindróma ritkábban előforduló tünetei közé tartozó lipomatosis a vizsgált család 
több tagjánál is előfordult. Terápiás próbálkozásként negyedévente piracetám infúziós kezelésben részesül a probanda, amely átmenetileg a szubjektív panaszait enyhíti.

Anyagi támogatás: A közlemény megírása anyagi támogatásban nem részesült. A kutatás eszközbeszerzése/infrastruktúrája egyéb, az OTKA 119540 pályázata (témavezető: Prof. Dr. Melegh Béla) által biztosított forrásból valósult meg.

Szerzői munkamegosztás: B. J., H. K., M. P.: A molekuláris genetikai vizsgálatok elvégzése, értékelése. H. K., N. A., F. A., T. Á.: Betegvizsgálat. F. A., H. K.: A kézirat megszövegezése. M. B.: A kézirat áttekintése. A cikk végleges változatát valamennyi szerző elolvasta és jóváhagyta.

Érdekeltségek: A szerzőknek nincsenek érdekeltségeik.

\section{Irodalom}

[1] Lorenzoni, P. J., Scola, R. H., Kay, C. S., et al.: When should MERRF (myoclonus epilepsy associated with ragged-red fibers) be the diagnosis? Arq. Neuropsiquiatr., 2014, 72(10), 803-811.

[2] Folbergrová, J. L., Kunz, W. S.: Mitochondrial dysfunction in epilepsy. Mitochondrion, 2012, 12(1), 35-40.

[3] Virgilio, R., Ronchi, D., Bordoni, A., et al.: Mitochondrial DNA G8363A mutation in the tRNA Lys gene: clinical, biochemical and pathological study. J. Neurol. Sci., 2009, 281(1-2), 85-92.
[4] Brackmann, F., Abicht, A., Abting, U., et al.: MERRF phenotype associated with mitochondrial tRNA(Leu) $(\mathrm{m} .3243 \mathrm{~A}>\mathrm{G})$ mutation. Eur. J. Pediatr., 2012, 171(5), 859-862.

[5] Teive, H. A., Munhoz, R. P., Muzzio, J. A., et al.: Cerebellar ataxia, myoclonus, cervical lipomas, and MERRF syndrome. Case report. Mov. Disord, 2008, 23(8), 1191-1192.

[6] Lorenzoni, P. J., Scola, R. H., Kay, C. S., et al.: MERRF: Clinical features, muscle biopsy and molecular genetics in Brazilian patients. Mitochondrion, 2011, 11(3), 528-532.

[7] DiMauro, S., Hirano, M., Kaufmann, P., et al.: Clinical features and genetics of myoclonic epilepsy with ragged red fibers. Adv. Neurol., 2002, 89, 217-229.

[8] Molnar, M. J., Perenyi, J., Siska, E., et al.: The typical MERRF (A8344G) mutation of the mitochondrial DNA associated with depressive mood disorders. J. Neurol., 2009, 256(2), 264-265.

[9] Kobayashi, J., Nagao, M., Miyamoto, K., et al.: MERRF syndrome presenting with multiple symmetric lipomatosis in a Japanese patient. Intern. Med., 2010, 49(5), 479-482.

[10] Muñoz-Málaga, A., Bautista, J., Salazar, J. A., et al.: Lipomatosis, proximal myopathy, and the mitochondrial 8344 mutation. A lipid storage myopathy? Muscle Nerve, 2000, 23(4), 538-542.

[11] Holme, E., Larsson, N. G., Oldfors, A., et al.: Multiple symmetric lipomas with high levels of mtDNA with the tRNA(Lys) $\mathrm{A} \rightarrow \mathrm{G}(8344)$ mutation as the only manifestation of disease in a carrier of myoclonus epilepsy and ragged-red fibers (MERRF) syndrome. Am. J. Hum. Genet., 1993, 52(3), 551-556.

(Fekete Anett dr., Pécs, József A. u. 7., 7623 e-mail: fekete.anett@pte.hu)

\section{Ellen Notbohm-Veronica Zysk} EZEREGY NAGYSZERRUU ÖTLET AUTIZMUSSAL ÉLŐ VAGY ASPERGER-SZINDRÓMÁS GYEREKEK NEVELÉSÉHEZ ÉS TANÍTÁSÁHOZ

„Ha minden iskolában és családban a könyvben szereplő ötletek kis töredékét felhasználnák, beláthatatlan lehetöségek nyilinának meg elöttünk, hogy javítsuk az autizmussal vagy Asperger-szindrómával élo" gyermekek életminőségét. Ez pedig csodálatos dolog!"

A könyv számtalan azonnal alkalmazható ötletet

Dr. Temple Grandin kínál szülőknek és nevelőknek az alábbi területeken:

- szenzoros integráció: fejlesztőfeladatok a szabadban és bent

- kommunikáció: szóhasználat, hallás, vizualitás, környezet,

- viselkedés: tipikus viselkedési formák és kezelésük,

- mindennapi élet: ötletek a mindennapi szituációkhoz, a biztonság megteremtéséhez,

- szociális létezés: barátság, játék, kooperáció, érzelmek. 